\title{
Myopathy Associated with Acute Hypothyroidism following Radioiodine Therapy for Graves Disease in an Adolescent
}

\author{
Valeria C. Benavides and Scott A. Rivkees \\ Section of Endocrinology, Department of Pediatrics, Yale Pediatric Thyroid Center, Yale University School of Medicine, New Haven, \\ CT 06520, USA \\ Correspondence should be addressed to Scott A. Rivkees, scott.rivkees@yale.edu
}

Received 24 May 2010; Accepted 27 July 2010

Academic Editor: Catherine Dinauer

Copyright (๑) 2010 V. C. Benavides and S. A. Rivkees. This is an open access article distributed under the Creative Commons Attribution License, which permits unrestricted use, distribution, and reproduction in any medium, provided the original work is properly cited.

\begin{abstract}
We describe acute myopathy following I-131 treatment for hyperthyroidism due to Graves Disease (GD) in an adolescent. A 15 year-old diagnosed with GD required treatment with radioactive iodine (I-131) therapy. Six weeks post I-131, he developed generalized muscle cramps. The CK was $19.800 \mathrm{U} / \mathrm{L}$, the total thyroxine was $2.3 \mathrm{mcg} / \mathrm{dL}(29.6 \mathrm{nmol} / \mathrm{L} \mathrm{SI})$ and the estimated free thyroxine (EFT) was $0.5 \mathrm{ng} / \mathrm{dL}(6.4 \mathrm{pmol} / \mathrm{L} \mathrm{SI})$. The ALT was $112 \mathrm{U} / \mathrm{L}$ and AST was $364 \mathrm{U} / \mathrm{L}$ (normal $<35 \mathrm{U} / \mathrm{L}$ ). The muscle cramps and CK elevation normalized five months after initiation of thyroid replacement therapy. This observation shows that acute myopathy can rarely occur in pediatric patients with GD following treatment with I-131.
\end{abstract}

\section{Introduction}

Graves Disease (GD) is uncommon in children with an estimated incidence of 1 per 10,000 [1]. GD accounts for $95 \%$ of the cases of hyperthyroidism in children and is more frequent in those with a familial history of autoimmune thyroid disease [2]. Although pharmacological therapy with antithyroid drugs (ATDs) is the first-line therapy in pediatric GD, long-term remission rates of GD in children are less than $25 \%$ [3]. Thus, definitive treatment with radioactive iodine (RAI, I-131) or surgery is required for the majority of individuals with GD $[3,4]$. When I-131 is used, the treatment goal is hypothyroidism which typically occurs $2-4$ months after the administered dose $[5,6]$.

Muscle abnormalities can occur in hypothyroidism via mechanisms that are unclear [7]. Hypothyroidism-related myopathy has been observed in adults and children [8], with a wide spectrum of problems including myalgias, proximal myopathy, and muscle hypertrophy [7]. Elevation of serum creatine kinase $(\mathrm{CK})$, associated with rhabdomyolysis and renal complications, has been reported [9-12]. Fifty seven to $90 \%$ hypothyroid individuals can have CK elevations $[13,14]$, a phenomenon not observed in hyperthyroidism [15].
Acute myopathy with onset during the acute hypothyroidism following treatment of GD is rare in adults [16]. Severe rhabdomyolysis, a more severe state where elevation of muscle enzymes is additionally associated with myoglobinuria, elevated creatinine, and renal failure, has also been observed in this setting $[17,18]$. In children, myopathy with hypothyroidism is rare [19], and we are unaware of reports of acute myopathy following 131-I treatment in the pediatric population. We now describe acute myopathy following I-131 treatment for hyperthyroidism due to GD in an adolescent.

\section{Case Report}

A 15-year-old male was diagnosed with GD. At presentation, there was goiter (estimated 40-60 grams of thyroid tissue). The total thyroxine (T4) was $27.8 \mathrm{mcg} / \mathrm{dL}$ $(357.8 \mathrm{nmol} / \mathrm{L}$ SI) (normal $4.5-12.5 \mathrm{mcg} / \mathrm{dL}$ ), estimated free thyroxine (EFT) $6.6 \mathrm{ng} / \mathrm{dL}$ ( $85 \mathrm{pmol} / \mathrm{L}$ SI) (normal $1.1-2.2 \mathrm{ng} / \mathrm{dL}$ ), thyrotropin-stimulating hormone (TSH) $<0.01 \mathrm{uIU} / \mathrm{mL}$ (normal $0.35-4.35 \mathrm{uIU} / \mathrm{mL}$ ); total triiodothyronine (T3) was $490 \mathrm{ng} / \mathrm{dL}$ ( $7.5 \mathrm{nmol} / \mathrm{L} \mathrm{SI}$ ) (normal 47-186 ng/dL) (Table 1). 
TABLE 1: Biochemical test results over time.

\begin{tabular}{lccccc}
\hline & T4 $(5-10.6 \mathrm{mcg} / \mathrm{dL})$ & EFT $(1.1-2.2 \mathrm{ng} / \mathrm{dL})$ & CK $(24-195 \mathrm{U} / \mathrm{L})$ & ALT $(0-35 \mathrm{U} / \mathrm{L})$ & AST $(0-35 \mathrm{U} / \mathrm{L})$ \\
\hline Diagnosis of GD & 27.8 & 6.6 & - & 20 & 27 \\
Myopathy onset & 2.3 & 0.5 & 19,800 & 242 & 112 \\
5 months after 131-I & 10.5 & 2 & 69 & 14 & 16 \\
\hline
\end{tabular}

T4, total thyroxine levels; EFT, estimated free thyroxine; CK, Creatine kinase; ALT, alanine aminotransferase; ALT, aspartate aminotransferase. Normal ranges are shown in parenthesis.

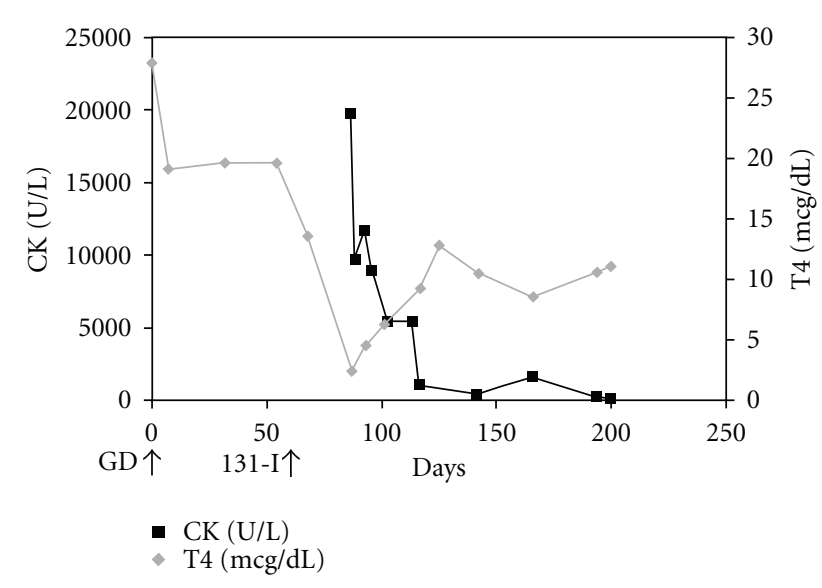

FIGURE 1: Serial changes in creatine kinase (CK) and total thyroxine (T4) levels. GD: onset of Graves Disease, 131-I: radioactive iodine treatment.

His past medical history was unremarkable. He was treated with $20 \mathrm{mg}$ of methimazole (MMI) per day and atenolol. One month into treatment, he developed neutropenia. The MMI was discontinued, and the patient was treated with $15.2 \mathrm{mCi}$ of 131-I five days later. The 123-I uptake prior to 131 -I therapy was $>95 \%$ in the neck. A $99-$ Tc scan showed diffuse uptake over the thyroid. At the time of treatment, the $\mathrm{T} 4$ was $19.5 \mathrm{mcg} / \mathrm{dL}(251 \mathrm{nmol} / \mathrm{L} \mathrm{SI})$, and the EFT was $6.5 \mathrm{ng} / \mathrm{dL}$ ( $83.6 \mathrm{pmol} / \mathrm{L} \mathrm{SI})$. Four weeks later, the goiter had decreased in size, the WBC was $3.1 \cdot 10^{3} / \mathrm{uL}$, the absolute neutrophil count (ANC) was $2.3 \cdot 10^{3}$ cells/uL, and the T4 was $13.4 \mathrm{mcg} / \mathrm{dL}(172.4 \mathrm{nmol} / \mathrm{L} \mathrm{SI})$.

Six weeks after 131-I treatment, he developed sudden onset of generalized muscle cramps. The CK was 19.800 U/L (normal 24-195 U/L), with an increased CKMB fraction of $13.9 \mathrm{ng} / \mathrm{mL}$ (normal $<5 \mathrm{ng} / \mathrm{mL}$ ). TroponinI levels and an electrocardiogram were normal. The total T4 was $2.3 \mathrm{mcg} / \mathrm{dL}(29.6 \mathrm{nmol} / \mathrm{L} \mathrm{SI})$, and the EFT was $0.5 \mathrm{ng} / \mathrm{dL}(6.4 \mathrm{pmol} / \mathrm{L} \mathrm{SI})$. The ALT was $112 \mathrm{U} / \mathrm{L}$, and AST was $364 \mathrm{U} / \mathrm{L}$ (normal <35 U/L). There was no evidence of myoglobinuria or electrolyte abnormalities. Renal function was normal. He received intravenous hydration and was placed on levothyroxine $(125 \mathrm{mcg} / \mathrm{day})$. He continued to have milder muscle cramps which resolved over the next three months. Neurological evaluation did not reveal an intrinsic myopathy. Five months after starting levothyroxine therapy, CK levels normalized (Figure 1).

\section{Discussion}

Acute myopathy in GD was initially reported in an adult treated with 131-I, who presented with muscle cramps and CK elevation six weeks after treatment, a condition that resolved with the correction of the hypothyroid state [16]. Severe rhabdomyolysis was reported in a patient with papillary thyroid cancer two weeks after total thyroidectomy [17]. Adults have been reported to have developed either myopathy or rhabdomyolysis following the sudden onset of hypothyroidism $[18,20,21]$. The magnitude of CK elevations in these individuals was postulated to be related to the degree of hypothyroidism [14]; however, such correlations have not been found by others [22]. Acute myopathy has also been described in individuals undergoing GD treatment with thionamides $[15,18,23]$. CK elevations during medical treatment of GD, in the absence of a hypothyroid state in two children, have been reported too [19].

The pathogenesis of hypothyroid myopathy is not yet well understood. It has been suggested that thyroxine deficiency leads to an abnormal glycogenolysis [21], metabolic disturbances in mitochondrial oxidative metabolism and triglyceride turnover, which impairs muscle function [24]. Muscle biopsies performed in this setting reveal nonspecific changes, including type II fiber atrophy [25]. It has also been suggested that a reversible, acquired glycogen storage and mitochondrial disorder is a part of hypothyroid myopathy $[13,26]$.

Although a muscle biopsy was not performed, formal neurological evaluation did not reveal a potential for underlying myopathic condition. Following normalization of CK levels, they have remained normal even in the face of rigorous physical activity. Of note, the decline in T4 levels subsequent to 131-I therapy in our patient was also not unusual in comparison with that reported in pediatric patients [5]. Thus, at present, a specific cause for myopathy, other than acute onset hypothyroidism, cannot be discerned.

Over the past two decades of 131-I use in the treatment of GD in pediatric patients at our institution, this is the only individual to have developed this problem. Thus, we estimate the incidence of myopathy following 131-I therapy on GD to be less than $0.5 \%$ in children.

\section{References}

[1] S. Williamson and S. A. Greene, "Incidence of thyrotoxicosis in childhood: a national population based study in the UK and Ireland," Clinical Endocrinology, vol. 72, no. 3, pp. 358-363, 2010. 
[2] F. Kaguelidou, J. C. Carel, and J. Léger, “Graves' disease in childhood: advances in management with antithyroid drug therapy," Hormone Research, vol. 71, no. 6, pp. 310-317, 2009.

[3] S. A. Rivkees, "The treatment of graves' disease in children," Journal of Pediatric Endocrinology and Metabolism, vol. 19, no. 9, pp. 1095-1111, 2006.

[4] S. A. Rivkees and C. Dinauer, "Controversy in clinical endocrinology: an optimal treatment for pediatric Graves' disease is radioiodine," Journal of Clinical Endocrinology and Metabolism, vol. 92, no. 3, pp. 797-800, 2007.

[5] T. D. Nebesio, A. R. Siddiqui, O. H. Pescovitz, and E. A. Eugster, "Time course to hypothyroidism after fixed-dose radioablation therapy of Graves' disease in children," Journal of Pediatrics, vol. 141, no. 1, pp. 99-103, 2002.

[6] S. A. Rivkees and E. A. Cornelius, "Influence of iodine131 dose on the outcome of hyperthyroidism in children," Pediatrics, vol. 111, no. 4, pp. 745-749, 2003.

[7] M. Cakir, N. Samanci, N. Balci, and M. K. Balci, "Musculoskeletal manifestations in patients with thyroid disease," Clinical Endocrinology, vol. 59, no. 2, pp. 162-167, 2003.

[8] A. Galli-Tsinopoulou, C. Stylianou, P. Kokka, P. Panagopoulou, and S. Nousia-Arvanitakis, "Rhabdomyolysis, renal failure, pericardial effusion, and acquired von Willebrand disease resulting from hypothyroidism in a 10-year-old girl," Thyroid, vol. 18, no. 3, pp. 373-375, 2008.

[9] G. George, "Hypothyroidism presenting as puzzling myalgias and cramps in 3 patients," Journal of Clinical Rheumatology, vol. 13, no. 5, pp. 273-275, 2007.

[10] M. Rabhi, J. Chaari, and F. Toloune, "Rhabdomyolysis disclosing hypothyroidism," European Journal of Internal Medicine, vol. 17 , no. 3 , p. $220,2006$.

[11] J. Finsterer, C. Stöllberger, C. Grossegger, and A. Kroiss, "Hypothyroid myopathy with unusually high serum creatine kinase values," Hormone Research, vol. 52, no. 4, pp. 205-208, 1999.

[12] G. Kisakol, R. Tunc, and A. Kaya, "Rhabdomyolysis in a patient with hypothyroidism," Endocrine Journal, vol. 50, no. 2, pp. 221-223, 2003.

[13] R. O. McKeran, G. Slavin, P. Ward, E. Paul, and W. Mair, "Hypothyroid myopathy. A clinical and pathological study," Journal of Pathology, vol. 132, no. 1, pp. 35-54, 1980.

[14] Z. Hekimsoy and I. K. Oktem, "Serum creatine kinase levels in overt and subclinical hypothyroidism," Endocrine Research, vol. 31, no. 3, pp. 171-175, 2005.

[15] D. Shaheen and C. S. Kim, "Myositis associated with the decline of thyroid hormone levels in thyrotoxicosis: a syndrome?" Thyroid, vol. 19, no. 12, pp. 1413-1417, 2009.

[16] A. W. C. Kung, J. T. C. Ma, Y. L. Yu et al., "Myopathy in acute hypothyroidism," Postgraduate Medical Journal, vol. 63, no. 742, pp. 661-663, 1987.

[17] R. P. Espiritu and M. N. Stan, "Rhabdomyolysis after withdrawal of thyroid hormone in a patient with papillary thyroid cancer," Endocrine Practice, vol. 14, no. 8, pp. 1023-1026, 2008.

[18] V. Andía Melero, A. López-Guzmán, Á. Fraile Sáez, and A. Arranz Martín, "Rhabdomiolysis secondary to antithyroid drugs," Medicina Clinica, vol. 129, no. 18, p. 717, 2007.

[19] H. Mizuno, Y. Sugiyama, Y. Nishi, N. Ueda, Y. Ohro, and H. Togari, "Elevation of serum creatine kinase in response to medical treatment of Graves' disease in children," Acta Paediatrica, vol. 95, no. 2, pp. 243-245, 2006.

[20] I. Kurihara, "Rhabdomyolysis in a patient with postoperative hypothyroidism and hypoparathyroidism," Nippon Jinzo Gakkai Shi, vol. 50, no. 1, pp. 59-63, 2008.
[21] J. E. Riggs, "Acute exertional rhabdomyolyses in hypothyroidism: the result of a reversible defect in glycogenolysis?" Military Medicine, vol. 155, no. 4, pp. 171-172, 1990.

[22] B. Saha and C. Maity, "Alteration of serum enzymes in primary hypothyroidism," Clinical Chemistry and Laboratory Medicine, vol. 40, no. 6, pp. 609-611, 2002.

[23] L. Soriano Guillén, M. Martín Díaz, M. Muñoz Calvo, J. Pozo Román, and J. Argente Oliver, "Myositis secondary to antithyroid treatment," Anales de Pediatría, vol. 66, pp. 625626, 2007.

[24] A. A. Khaleeli, D. G. Griffith, and R. H. T. Edwards, "The clinical presentation of hypothyroid myopathy and its relationship to abnormalities in structure and function of skeletal muscle," Clinical Endocrinology, vol. 19, no. 3, pp. 365376, 1983.

[25] R. O. McKeran, G. Slavin, T. M. Andrews, P. Ward, and W. Mair, "Muscle fibre type changes in hypothyroid myopathy," Journal of Clinical Pathology, vol. 28, no. 8, pp. 659-663, 1975.

[26] G. Pellegrini and M. Moggio, "Hypothyroid myopathy: histochemical and ultrastructural features with physiopatological correlations (author's transl)," Rivista di Patologia Nervosa e Mentale, vol. 99, no. 5, pp. 275-288, 1979. 